\title{
BeleidsonderzoekOnline
}

DOI: 10.5553/Beleidsonderzoek.000515

\section{Motieven en overwegingen achter publiek-private samenwerking}

Arno Eversdijk en Arno F.A. Korsten

\begin{abstract}
Aanbevolen citeerwijze bij dit artikel
Arno Eversdijk en Arno F.A. Korsten, 'Motieven en overwegingen achter

publiek-private samenwerking', Beleidsonderzoek Online februari 2015, DOI:

10.5553/Beleidsonderzoek.0o0515
\end{abstract}

Sinds het midden van de jaren tachtig van de vorige eeuw zijn op rijksniveau veel pleidooien gehouden voor publiek-private samenwerking (PPS): in regeerakkoorden, overheidsnota's en rapporten van commissies. Het Nederlandse parlement uitte zich ook vaak pro PPS. Tal van kabinetten wisten steeds meerderheden mee te krijgen en als de bestuurlijke aandacht verslapte, werden breed vanuit het parlement aansporingen geuit. Hoewel PPS dus betrekkelijk onomstreden was, bleek in ambtelijke kringen in het eerste decennium na 1985 aarzeling. De voordelen van PPS werden niet overal gezien, een afbraak van Rijkwaterstaat werd gevreesd en PPS impliceerde een breuk met ingesleten werkwijzen. Maar Rijkswaterstaat zou na een aarzelende showcase toch omgaan. Kwam het ook in concrete gevallen tot PPS, zoals in Groot-Brittannië? En wat waren dan de concrete motieven? Financiële meerwaarde, daar moest het om gaan. Het instrument van de Public Private Comparator (PPC) werd als vergelijkings- en afwegingsinstrument geïntroduceerd bij rijksinsfrastructuurprojecten. In dit artikel is nagegaan wat de bevindingen waren van in de periode 1986-2011 hierbij toegepaste PPC-en. Het onderzoek wijst uit dat in de praktijk de PPC hier en daar ook naar financiële meerwaarde wees en de PPC ook uitmondde in PPS. Maar in tal van gevallen was de meerwaarde als motivering niet voldoende en waren bestuurlijke motieven nodig om de doorslag te geven pro PPS. Soms was de meerwaarde ook beargumenteerd maar ging een PPS toch niet door. Het bereiken van financiële meerwaarde is dus wel het officieel doel of motief gebleken 
maar was in de praktische besluitvorming lang niet altijd de enige relevante factor. Meerwaarde was niet genoeg. Begrijpelijk, soms was de veronderstelde meerwaarde ook betrekkelijk klein. Op momenten dat het rijksbudget voor weginfrastructuur als meer dan voldoende werd beoordeeld en een project topprioriteit had, kwam het helemaal niet tot PPS. PPS is dus niet altijd wat het lijkt.

\section{Inleiding}

Meer overlaten aan bedrijven en inkrimpen van het overheidsapparaat vormden ten tijde van het tweede kabinet-Lubbers (1986-1989) drijvende krachten achter de opkomst van publiek-private samenwerking (PPS) in Nederland. Het kabinet stond daarin niet alleen. Destijds had het politiek bestuur van het Verenigd Koninkrijk onder leiding van premier Thatcher al enige ervaring opgedaan met PPS. De private gelden ter financiering van achterstallig onderhoud aan gebouwen en weginfrastructuur bleken destijds voor de Britse regering een welkome aanvulling van de schatkist (Greve, 2007: 122). De voordelen van dit fenomeen lonkten ook in Nederland naar publieke bestuurders. Het toenmalige Nederlandse kabinet kon de verleiding niet weerstaan en de publieke interesse in PPS was ook hier geboren. Van bijwerkingen had men toen nog nauwelijks notie.

PPS paste binnen de maatschappelijke stroming van New Public Management (NPM), waarin de werking van overheidsorganisaties door een bedrijfsmatige bril werd bekeken.'Run government like a business' werd het adagium (Osborne \& Gaebler, 1992; Bovens et al., 2001: 193; Barzelay, 2001; McLaughlin, Osborne \& Ferlie, 2002). Private inzet via publiek-private samenwerkingsverbanden moest de effectiviteit en efficiency van het overheidsoptreden bij grote projecten verder bevorderen. Maar wat toont de praktijk? Hoewel PPS veelbelovend was, bleek de acceptatie van PPS in Nederland op nationaal niveau geen gelopen race. Hoe kon dat? Ongeveer vijftien jaar belijdenis van PPS in rijksnota's ging gepaard met tal van pleidooien om voor PPS te kiezen en op de politieke agenda te houden. Maar feitelijk viel de keuze in concrete gevallen slechts sporadisch op PPS. Achterliggende motieven die het PPS-beleid moesten rechtvaardigen, varieerden en veranderden mee op de economische en ideologische golfbewegingen in de maatschappij (Eversdijk, 2013: 185). Begrijpelijk. Wat niet van uit zichzelf volledig overtuigend is, behoeft aanvullende argumentatie. Hodge et al. (2010) spreken van een taalspel, a language game. Wij karakteriseren het gevoerde PPS-beleid eerder als een multi-motive-policy; een voorbeeld van verbale vernieuwing, gericht op het continue genereren van nieuw elan, met andere woorden.

Wat zijn de keuzen en overwegingen die overheidsbestuurders op zowel politiek-bestuurlijk als op (top-)ambtelijk niveau maken? Waarom en hoe kiezen bestuurders voor PPS bij weginfrastructurele projecten? Dat is het onderwerp van dit artikel, dat handelt over het wel of niet kiezen 
van PPS bij rijksinfrastructurele projecten in de periode 1986-2011, een kwart eeuw. Voor de beantwoording is onder meer uitgebreid gebruikgemaakt van schriftelijk materiaal dat betrekking heeft op tal van rijksprojecten en er zijn gesprekken gevoerd met tal van actoren (zie ook Eversdijk \& Korsten, 2008; Eversdijk, 2013).

\section{PPS omschreven}

PPS duidt op een samenwerkingsrelatie tussen publieke partijen, overheden enerzijds en private ondernemingen, zoals bouwbedrijven en banken anderzijds. Deze partijen gaan een of meer langjarige overeenkomsten aan voor de realisatie van publieke voorzieningen, zoals gebouwen, gevangenissen of de aanleg en het onderhoud van wegen, viaducten of bruggen. In de regel gaat het in Nederland om overeenkomsten met een looptijd van twintig tot dertig jaar. De locus van het PPS-onderzoek, dat hier aan de orde is, betreft de weginfrastructuur op rijksniveau.

Een PPS-overeenkomst houdt in hoofdlijnen in dat een consortium van (bouw)ondernemingen in ongeveer vier jaar tijd een rijksweg of tunnel realiseert en deze conform de overeenkomst vervolgens ongeveer twintig jaar onderhoudt. Ook financiële instellingen, zoals banken, zijn betrokken bij de realisatie van het project. Zij dragen namelijk zorg voor de benodigde externe financiering van het project. Gemakshalve mag dit worden gezien als een vorm van voorfinanciering door het consortium. $\mathrm{Na}$ de realisatiefase volgt de onderhoudsfase. Tijdens de onderhoudsperiode betaalt de publieke opdrachtgever het consortium voor zijn prestaties, mits hij voldoet aan de contracteisen. Deze betalingen vormen de inkomstenbron van het private consortium waarmee dit zijn externe financiering bij de financier kan inlossen.

\section{Bevlogenheid bij kabinetten}

Bij diverse Nederlandse kabinetten zijn de verwachtingen over PPS hooggespannen geweest. Tussen 1986 en 2011 waaide gedurende perioden tussen verkiezingen zelfs een haast ontembare bevlogenheid door de Haagse parlementen; PPS moest en zou worden toegepast. Ondanks deze collectieve parlementaire wil en het heersende politieke primaat bleek het toepassen van PPS bij rijksinfrastructurele projecten echter niet vanzelfsprekend. Vanaf 2007 werd PPS feitelijk slechts mondjesmaat toegepast.

Waarom werd PPS omarmd? Met PPS ontstonden voor het landsbestuur voordelen bij de aanleg en het onderhoud van infrastructuur, zoals financiële voordelen en het benutten van private expertise. Voordelen die met name worden bereikt door de overdracht van projectrisico's. In de PPS-literatuur bestaan echter onzekerheid en discussie over de algemene voordelen van PPS. Zo blijkt het empirisch bewijs om binnen de infrastructuur met PPS echte innovaties en (financiële) meerwaarden te kunnen halen twijfelachtig en diffuus (Skelcher, 2005: 360). En 
sommige evaluaties bieden een tegenstrijdig beeld (Hodge \& Greve, 2007: 553).

Naast deze constateringen blijkt uit de praktijk dat sommige verwachtingen afgeleid uit de PPS-literatuur niet aansluiten op de bestuurlijke context waarin keuzen worden gemaakt. Zo worden horizontale samenwerkingsverbanden, zoals PPS, in de literatuur soms verhuld in romantiek (PPS als een soort huwelijk tussen publiek en privaat) of soms geportretteerd als een ideaaltypische samenwerkingsrelatie, terwijl in werkelijkheid zakelijke of eigen financiële bedrijfsbelangen worden verdedigd. De feitelijke besluitvorming over PPS op rijksniveau is echter te typeren als een blackbox; deze is onduidelijk en weinig transparant.

Dit geheel aan constateringen wakkerde de nieuwsgierigheid aan om meer inzicht te krijgen in de publieke besluitvormingspraktijk van PPS op rijksniveau. Vandaar dit artikel.

\section{Verantwoording van het onderzoek}

Welke motieven en specifieke overwegingen liggen in het publieke domein daadwerkelijk ten grondslag aan de keuze om pro en soms contra PPS te kiezen? Binnen het publieke domein zijn macro- en micromotieven te onderscheiden (Eversdijk, 2013: 140, 184, 239 en 240). Macro-motieven zijn de motieven die binnen de politiekbestuurlijke arena werden gehanteerd door tal van kabinetten om het gewenste PPS-beleid te rechtvaardigen. Het zijn de motieven die we aantreffen in nota's. Motieven die vooral op ambtelijk niveau de keuze pro of contra PPS voor een bepaald rijksproject domineren, worden aangeduid als micro-motieven.

De eerdergenoemde onderzoeksvraag is langs drie wegen bestudeerd, namelijk via een literatuurstudie, een breedtestudie en dieptestudies (ook Eversdijk, 2013). De literatuurstudie was gericht op het verkennen van concepten en begrippen, empirisch gefundeerde bevindingen, en op het formuleren van verwachte uitkomsten van het onderzoek. De breedtestudie ging over de PPS-ambities van kabinetten, en opvattingen van ministers en (top)ambtenaren van Rijkswaterstaat en over de vraag hoe de invoering van PPS op rijksniveau verliep. Tot slot waren de dieptestudies gericht op het verfijnen van het beeld uit de breedtestudie. Wie keuzen wil begrijpen, moet namelijk de context kennen. Daarom zijn de publieke keuzeprocessen bestudeerd van vier infrastructurele wegprojecten en twee gebiedsgebonden projecten waarbij wel of niet voor PPS is gekozen. Dit gaf inzicht in de gehanteerde motieven pro of contra PPS binnen de maatschappelijke en bestuurlijke context van een project.

De vier infrastructurele (rijks)cases waren: de N31-Wâldwei (het eerste PPS-project voor Rijkswaterstaat), de Tweede Coentunnel, A2Hooggelegen en de N31-De Haak om Leeuwarden. Bij het laatste project 
werd niet gekozen voor PPS, terwijl dat wel de verwachting was gelet op de uitkomst van de Public-Private Comparator, de PPC. De PPC berekende een financiële meerwaarde met PPS ten opzichte van een minder verregaande vorm van private inzet.

De selectie van twee gebiedsgebonden cases, namelijk de ontwikkeling van Meerstad Groningen en Wieringerrandmeer, was gebaseerd op de bevindingen uit de literatuurstudie. Binnen de verscheidenheid aan PPSvormen die de PPS-literatuur rijk is, zijn deze in de kern namelijk terug te brengen tot twee hoofdvormen, deconcessievorm en de alliantievorm. De concessievorm van PPS in de vorm van een DBFM-overeenkomst domineert bij weginfrastructurele rijksprojecten, terwijl we de alliantievorm veelal bij gebiedsontwikkeling tegenkomen (Eversdijk, 2013).

Een Design-Build-Finance-Maintain-overeenkomst, kortweg DBFM, betreft een integrale overeenkomst waarbij de publieke opdrachtgever zowel het ontwerp (D), de bouw (B), het onderhoud (M) als de financiering (F) uitbesteedt aan een privaat consortium van bouwbedrijven en banken. In tegenstelling tot de concessie-PPS is de alliantie-PPS meer gestoeld op gelijkwaardig partnerschap, meer gericht op het gezamenlijk oprichten en uitvoeren van een project. Zo komt het 'samen denken-doen-delen'-principe bij de alliantievorm meer tot uitdrukking.

Hoewel de alliantievorm in de bestuurskundige literatuur wordt bejubeld, deze zou namelijk PPS zijn zoals PPS bedoeld is, blijkt deze vorm tot op heden een bestuurskundige mythe, althans bij infrastructurele projecten in Nederland (Eversdijk \& Korsten, 2008). Ook anno 2015 is de alliantie-PPS op rijksniveau bij het realiseren van weginfrastructuur vooralsnog ongebruikelijk. Gebaseerd op de literatuur waren onze verwachtingen voorafgaand aan het onderzoek dus anders. Dat gold ook voor twee andere verwachte uitkomsten ('hypothesen') die in dit artikel centraal staan. Het betreft:

1. de verwachting dat PPS vanzelfsprekend tot stand komt;

2. de verwachting dat bij financiële meerwaarde voor PPS ook voor (concessie-)PPS wordt gekozen.

\section{Vanzelfsprekend of niet?}

De verwachting was dat PPS vanzelfsprekend van de grond zou komen. Immers, PPS was een veelbelovende keuze in meerdere kabinetsnota's. Tal van regeerakkoorden spraken zich uit vóór PPS. En ook in de Tweede Kamer was het enthousiasme voor PPS haast ontembaar. Maar, wat kwam er van de grond vanaf 1986? Tabel 1 illustreert de hoeveelheid weginfrastructurele projecten die tussen 1986 en 2011 in PPS-verband tot stand kwamen.

Tabel 1 Besluiten tot PPS bij weginfrastructurele projecten, naar jaar 


\begin{tabular}{|c|c|c|c|c|c|c|c|c|c|}
\hline Project & $\begin{array}{l}\text { PPS- } \\
\text { vorm }\end{array}$ & Jaar & & & & & & & \\
\hline & & 1988 & 1992 & 2003 & 2006 & $\mathbf{2 0 0 7}$ & 2008 & 2010 & 2011 \\
\hline Noordtunnel & DBFM & $\bullet$ & & & & & & & \\
\hline Wijkertunnel & DBFM & & $\bullet$ & & & & & & \\
\hline A59 & DBFM & & & $\bullet$ & & & & & \\
\hline N31 & DBFM & & & $\bullet$ & & & & & \\
\hline $\mathrm{N} 2 \mathrm{O} 1$ & DBFM & & & & $\bullet$ & & & & \\
\hline $\begin{array}{l}\text { A2- } \\
\text { Hooggelegen }\end{array}$ & Alliantie & & & & & $\bullet$ & & & \\
\hline $\begin{array}{l}\text { Tweede } \\
\text { Coentunnel }\end{array}$ & DBFM & & & & & & $\bullet$ & & \\
\hline $\begin{array}{l}\text { A12 } \\
\text { Lunetten - } \\
\text { Veenendaal }\end{array}$ & DBFM & & & & & & & $\bullet$ & \\
\hline $\begin{array}{l}\text { A15 } \\
\text { Maasvlakte - } \\
\text { Vaanplein }\end{array}$ & DBFM & & & & & & & $\bullet$ & \\
\hline
\end{tabular}

Uit tabel 1 blijkt dat in de periode tussen 1986 en 2011 voor negen weginfrastructurele projecten PPS-overeenkomsten zijn gesloten, waarvan acht in een concessievorm (DBFM) en één in een alliantievorm van PPS. Op rijksniveau werden geen PPS-overeenkomsten gesloten in de jaren 1986, 1987, 1989 tot en met 1991, 1993 tot en met 1999, 2002, 2004, 2005, 2009 en 2011. Voor twee overeenkomsten was niet Rijkswaterstaat, maar een provinciebestuur opdrachtgever (A59 en N201). Uiteindelijk werden op rijksniveau (door Rijkswaterstaat) zeven PPS-overeenkomsten gesloten voor de realisatie van weginfrastructuur.

Is dat nu veel of weinig? Dit aantal is vergeleken met het aantal infrastructurele PPS-overeenkomsten in het Verenigd Koninkrijk. Het gedachtegoed van PPS is namelijk vanuit die natie komen overwaaien. De leiding van Rijkswaterstaat liet zich ook vanuit die hoek informeren en influisteren. De contractvorm DBFM is dan ook sterk geënt op het Britse Private Finance Initiative-concept (PFI). Klijn en Van Twist spreken in dit verband ook wel van een policy transfer (2007: 160).

In vergelijking met het Verenigd Koninkrijk betreft het aantal Nederlandse infrastructurele projecten dat in PPS-verband is gerealiseerd ongeveer een kwart van het aantal in het Verenigd Koninkrijk. Tussen 1987 en 2011 werden in het Verenigd Koninkrijk 
namelijk dertig weginfrastructurele projecten in PPS-verband gerealiseerd. In totaal sloot de Britse regering over diverse publieke projecten honderden PPS-overeenkomsten in de afgelopen drie decennia.

Tot aan de eeuwwisseling werd PPS in Nederland nauwelijks toegepast bij weginfrastructuur met een hoge prioriteit. Er bleek namelijk voldoende budget, er waren geen financiële problemen en PPS was destijds niet de oplossing voor de mobiliteitsvraagstukken, zo verklaarde voormalig directeur-generaal Gerrit Blom van Rijkswaterstaat in een interview met ons. Tijdens zijn dg-schap (1989-1998) was PPS niet het onderwerp waarover Blom sprak met de ministers van Verkeer en Waterstaat of andere ministers. Ministers hadden andere prioriteiten.

Na ongeveer vijftien jaar, zo rond 2000, kwam er wel wat beweging. Het parlement voerde de druk 'pro PPS' verder op. Doorslaggevend was de interventie van minister Gerrit Zalm van Financiën, en later ook verkeersminister Karla Peijs, die een indringend en niet te negeren beroep deden op de leiding van Rijkswaterstaat om met PPS door te pakken. Oud-minister Peijs bevestigde dit in 2012 in een interview nog eens tegenover ons. De redenering was: Rijkswaterstaat is te log, moet inkrimpen; PPS kan daarbij behulpzaam zijn. Als de leiding van Rijkswaterstaat niet zelf ingreep, dan zou het kabinet dit doen, zo dreigden de twee ministers.

De leiding van Rijkswaterstaat pakte PPS op, zo liet voormalig directeurgeneraal Bert Keijts ons weten. In 2003 volgende daarop een case. Voorzichtig nog, want het werd een showcase in de periferie (N31Wâldwei), ver weg van 'Den Haag'. Rijkswaterstaat boog mee, maar nog niet fors. Het initiëren van PPS verliep nog niet echt vlot. Er bleken dan ook tal van aanvullende impulsen nodig om PPS op de politieke agenda te houden. Ter illustratie noemen we hier het instellen van een Taskforce PPS (2004) en de onderzoekscommissie-Ruding (2008), het meeliften op rijksbreed veranderingsbeleid (Andere Overheid) of het organisatorisch verankeren van de PPS-gedachte door het oprichten van een kenniscentrum PPS bij het ministerie van Financiën (1999) en later (2006) bij Rijkswaterstaat. Ook binnen Rijkswaterstaat moest druk op de ketel blijven. Vanaf 2006-2007 nam het aantal PPS-projecten iets toe.

Hoewel de parlementaire verwachtingen over PPS dus hooggespannen waren, werden die lange tijd niet als zodanig waargemaakt. De vraag rees vervolgens: wisten parlementen geen vuist te maken? Was het parlement lam of leeuw? Verbaal een leeuw, maar feitelijk tot ongeveer 2000 een lam. Hoe kon dit gebeuren, want PPS werd door bewindslieden toch als veelbelovend ervaren?

We noemen hier drie oorzaken van het moeizame traject richting meer PPS:

1. Ten eerste drukten opeenvolgende ministers van Verkeer en 
Waterstaat niet echt door. Zij hadden vaak ook andere politieke prioriteiten dan scoren met PPS. Of ze vonden PPS een uitvoeringskwestie (minister Eurlings) en lieten de keuze pro of contra PPS over aan Rijkswaterstaat.

2. Ten tweede stonden ambtenaren van Rijkswaterstaat in het begin niet direct te juichen bij PPS. Zij hadden zo hun bedenkingen over de hoogte van de transactiekosten, die aan PPS-aanbestedingen kleven, en over de (beperkte) aanwezigheid van voldoende PPSdeskundigheid. PPS werd ervaren als een afbraak van kennis en werkwijzen. Rijkswaterstaat zou 'naar de knoppen gaan' als PPS zijn intrede zou doen. Zo werd PPS hier en daar beleefd. Kortom, het ontbrak aan ambtelijk draagvlak en initiatief.

3. Ten derde, PPS was in een regio bij een provinciebestuur en bij gemeentebesturen minder geliefd. Zo blijkt uit een van de casestudies dat zij een potentieel PPS-project tegenhielden om in PPS-verband te realiseren om daarmee de regionale aannemers te beschermen tegen de komst van grote bouwcombinaties op rijksprojecten.

Tot zover de belangrijkste bevindingen over de opkomst van PPS in Nederland bij infrastructurele rijksprojecten (meer in Eversdijk, 2013). De constatering dat het een moeizaam traject betrof, leidde ons naar de vraag: waarom willen overheidsbestuurders eigenlijk PPS? Oftewel, wat zijn nu de belangrijkste motieven van Nederlandse kabinetten geweest om in de periode 1986-2011 in algemene zin te pleiten voor PPS? Het betreft hier de politiek-bestuurlijke macro-motieven.

\section{Macro-motieven achter PPS}

In de afgelopen 25 jaar werden acht verschillende motieven gesignaleerd om de toepassing van PPS-beleid op nationaal niveau te rechtvaardigen (Eversdijk, 2013: 189). Zo bestond het 'motievenvocabulaire' uit een kasmotief, een doelmatigheidsmotief, een meerwaardemotief, een kwaliteitsmotief, een tijdsmotief, een klantmotief, een krimpmotief en een projectbeheersingsmotief. De motieven wisselden in de tijd en het palet aan motieven werd in de loop der tijd uitgebreid om te overtuigen, om PPS te promoten in Nederland. De macro-motieven werden gesignaleerd in PPS-voortgangsrapportages van de Tweede Kamer, vergaderverslagen van Vaste Kamercommissies, de regeerakkoorden tussen 1986 en 2011 en het Tweede Kamer-dossier 28753. We lichten de bevindingen kort toe.

De dominante factor bij de introductie van PPS in Nederland in 1986 was de 'financiële noodzakelijkheid'. Er waren investeringen nodig in de weginfrastructuur, echter tegelijkertijd waren er weinig publieke middelen voorhanden om deze te financieren. Privaat kapitaal was een welkome aanvulling om het verkeer- en vervoersbeleid van het toenmalige kabinet (Lubbers) te kunnen realiseren. 
In dezelfde periode kreeg ook het 'functioneren van de overheid' maatschappelijke aandacht. Het overheidsapparaat moest inkrimpen en de bureaucratie moest worden teruggedrongen. Dit streven moest leiden tot een meer efficiënte en effectieve manier van acteren van de rijksoverheid, waarbij de overheid zich weer meer kon richten op haar kerntaken. Was aanvankelijk sprake van een kasmotief, al snel volgde dus ook een doelmatigheidsmotief voor PPS. Niet alleen privaat kapitaal, maar ook aanvullende private kennis was namelijk gewenst.

Halverwege de periode 1986-2011, zo rond 1999, werd PPS door het toenmalige kabinet vooral gestimuleerd vanuit het motief om de kwaliteit van de publieke dienstverlening te verhogen respectievelijk te verbeteren. De inzet van PPS moest vooral leiden tot 'value-for-money' en meerwaarde, zowel financiële, inhoudelijke als maatschappelijke meerwaarde. De hogere kwaliteit liet en laat zich vertalen in een beoogde hogere beschikbaarheid en een snellere oplevering van de weginfrastructuur. Dit motief paste ook bij Rijkswaterstaat, die meer aandacht ging geven aan de dienstverlening richting de weggebruiker en aan het management van de verkeersstromen. De weggebruiker, lees de burger, stond centraal; het klantmotief was geboren. Zo vibreerde het PPS-motievenvocabulaire als het ware mee met de verschuivende tijdgeest waarin zeker na 2000 de burgers meer aandacht moesten krijgen. Tot slot verschijnt in 2010 een projectbeheersingsmotief ten tonele. Door de inzet van PPS zouden overheidsprojecten op tijd en binnen het geraamde budget worden gerealiseerd.

Soms popte een nieuw motief op, soms lag het nieuwe motief in het verlengde van het bestaande motief of overlapten ze elkaar wellicht deels. Vandaar onze eerdere constatering dat het PPS-beleid te karakteriseren is als een multi-motive-policy; voortdurende verbale vernieuwing waarbij de retoriek werd benut om de positieve verwachtingen over PPS te benadrukken.

Hoewel het kasmotief in de loop der tijd naar de achtergrond verschoof, treedt het vanaf 2008 weer meer op de voorgrond. Het is de periode waarin sprake is van een mondiale kredietcrisis. De PPSvoortgangsrapportage van 2010 wijst op de perspectieven die PPS in de vorm van DBFM kan bieden in tijden van budgettaire krapte en aangekondigde bezuinigingen.

De motieven achter het PPS-beleid veranderden niet alleen, maar deinden dus mee op de economische golfbewegingen in onze maatschappij. Ondanks de wisselende motieven is het opvallend te noemen dat op de achtergrond van het PPS-beleid de budgettaire krapte zich tot een rode draad ontwikkelde in de pleidooien pro PPS. Zo werden vanaf 1986 in diverse PPS-voortgangsrapportages (1988, 2002, 2004, 2010) het financieringstekort en de budgettaire krapte op de overheidsbegroting bij herhaling aangehaald als kans voor PPS. Dit verklaart ook waarom het landsbestuur continu op zoek was en is naar additionele financieringsbronnen, waarbij het publieke vizier gericht was 
en is op PPS.

De financiële meerwaarde geldt voor een overheidsbestuur als het belangrijkste motief om te kiezen voor toepassing van PPS (Greve, 2008: 10; Ministerie van V\& W \& Ministerie van Financiën, 2008: 1, 3). De vraag rijst vervolgens: was of is er bij de Nederlandse infrastructurele projecten dan geen of nauwelijks financiële meerwaarde voorzien, omdat PPS slechts sporadisch voorkwam? We gingen op zoek en keren dus weer terug naar de micro-analyse.

\section{Het meerwaarde-principe}

Een tweede verwachting ('hypothese') die we in dit betoog belichten, is de verwachting dat het Nederlandse overheidsbeleid bij PPS uitgaat van het zogenoemde 'meerwaarde-principe', zoals de commissie onder leiding van oud-minister Onno Ruding stelt (Ruding et al., 2008: 35). Dit principe betekent dat een overheidsbestuur bij projecten met een financiële omvang van 60 miljoen euro of meer voor PPS kiest als PPS financiële meerwaarde oplevert ten opzichte van een traditionele projectuitvoering.

De financiële meerwaarde wordt berekend aan de hand van de zogenoemde Public Private Comparator (PPC). De PPC is een financieel afwegingsinstrument, waarmee de verwachte financiële meerwaarde van PPS ambtelijk wordt berekend ten opzichte van een traditionele uitvoering van een project. De uitkomst van de PPC vormt in de praktijk het fundament voor de keuze voor wel of geen toepassing van PPS.

Rijkswaterstaat hecht veel waarde aan de PPC, want alleen met toestemming van de directeur-generaal mag worden afgeweken van de PPC-uitkomst. Analyse van de PPC-en zou dus inzicht moeten verschaffen of conform het 'meerwaarde-principe' werd gekozen voor PPS.

Voor de PPC-analyse zijn alle PPC-en verzameld die Rijkswaterstaat vanaf de introductie van de PPC in 2000 tot en met het einde van de onderzoeksperiode (2011) heeft opgesteld. In totaal ging het om 29 projecten waarvoor een PPC is uitgevoerd.

Tabel 2 PPC-uitkomsten en de keuze voor wel of geen PPS

\begin{tabular}{|c|c|c|}
\hline \multirow[t]{2}{*}{ Uitkomst PPC } & Publieke keuze & \\
\hline & $\begin{array}{l}\text { Wel gekozen voor } \\
\text { PPS }\end{array}$ & Géén PPS \\
\hline \multirow[t]{2}{*}{$\begin{array}{l}\text { Positief (= } \\
\text { meerwaarde voor } \\
\text { PPS is aanwezig) }\end{array}$} & 1. N31 & 1. A4 Delft-Schiedam \\
\hline & 2. Tweede & 2. A50 Ewijk- \\
\hline
\end{tabular}


Dit artikel uit Beleidsonderzoek Online is gepubliceerd door Boom bestuurskunde en is bestemd voor anonieme bezoeker

\begin{tabular}{|c|c|c|}
\hline & Coentunnel & Valburg \\
\hline & $\begin{array}{l}\text { 3. A15 Maasvlakte- } \\
\text { Vaanplein }\end{array}$ & $\begin{array}{l}\text { 3. A4 Omlegging } \\
\text { Steenbergen }\end{array}$ \\
\hline & $\begin{array}{l}\text { 4. A12 Utrecht- } \\
\text { Veenendaal }\end{array}$ & $\begin{array}{l}\text { 4. A2 Passage } \\
\text { Maastricht }\end{array}$ \\
\hline & $\begin{array}{l}\text { 5. Verdubbeling } \\
\text { RW33 Schiphol- } \\
\text { Amsterdam-Almere: }\end{array}$ & $\begin{array}{l}\text { 5. Schiphol- } \\
\text { Amsterdam-Almere: } \\
\text { Deelproject A1o Oost }\end{array}$ \\
\hline & $\begin{array}{l}\text { 6. A1-A6 Diemen- } \\
\text { Muiderberg }\end{array}$ & $\begin{array}{l}\text { 6. N31 Haak om } \\
\text { Leeuwarden }\end{array}$ \\
\hline & $\begin{array}{l}\text { 7. A9 } \\
\text { Gaasperdammerweg }\end{array}$ & $\begin{array}{l}\text { 7. Wilhelminakanaal } \\
\text { Tilburg }\end{array}$ \\
\hline & 8. A9 Amstelveen & $\begin{array}{l}\text { 8. Omlegging Zuid- } \\
\text { Willemsvaart }\end{array}$ \\
\hline & $\begin{array}{l}\text { 9. A6 Muiderberg- } \\
\text { Almere }\end{array}$ & $\begin{array}{l}\text { 9. Verruiming } \\
\text { Julianakanaal }\end{array}$ \\
\hline & $\begin{array}{l}\text { 10. Zeetoegang } \\
\text { IJmond }\end{array}$ & \\
\hline & $\begin{array}{l}\text { 11. A12 Ede- } \\
\text { Grijsoord }\end{array}$ & \\
\hline & 12. N18 Varsseveld & \\
\hline & $\begin{array}{l}\text { 13. Keersluis } \\
\text { Limmel }\end{array}$ & \\
\hline & $\begin{array}{l}\text { 14. A12/A15 } \\
\text { Arnhem-Nijmegen }\end{array}$ & \\
\hline \multirow[t]{6}{*}{$\begin{array}{l}\text { Negatief (= geen } \\
\text { meerwaarde } \\
\text { aanwezig voor } \\
P P S)\end{array}$} & 1. A2 Hooggelegen & $\begin{array}{l}\text { 1. Extra } \\
\text { Spuicapaciteit } \\
\text { Afsluitdijk }\end{array}$ \\
\hline & 2. Noordtunnel & $\begin{array}{l}\text { 2. A12 Utrecht West } \\
\text { (Gouda) }\end{array}$ \\
\hline & 3. Wijkertunnel & $\begin{array}{l}\text { 3. A2/A76 } \\
\text { Maatregelenpakket } \\
\text { Limburg }\end{array}$ \\
\hline & & $\begin{array}{l}\text { 4. A2 Maasbracht- } \\
\text { Geleen }\end{array}$ \\
\hline & & 5. A1/A6 \\
\hline & & $\begin{array}{l}\text { 6. A9 Omlegging } \\
\text { Badhoevedorp }\end{array}$ \\
\hline
\end{tabular}


Wat blijkt in de praktijk? Tabel 2 toont de 32 infrastructurele projecten die in aanmerking kwamen voor bezinning op wel of geen PPS én waarvoor tot eind 2011 de keuze was gemaakt of het betreffende project wel of niet in PPS-verband wordt gerealiseerd (vóór of ná 2011). Voor drie wegenprojecten werd geen PPC opgesteld, te weten voor A2 Hooggelegen, Noordtunnel en Wijkertunnel.

Uit de analyse van de PPC-en komt naar voren dat van alle in de periode van onderzoek uitgevoerde PPC-en uiteindelijk de helft niet leidt tot een keuze vóór PPS. Bovendien bleek dat bij veertig procent van de projecten waarbij uit de PPC een financiële meerwaarde rolde voor PPS, toch niet is gekozen voor PPS. Tabel 2 maakt deze constateringen nog eens inzichtelijk.

Kortom, we mogen concluderen dat het meerwaarde-principe niet altijd is gevolgd. De PPC-uitkomst bleek niet steeds doorslaggevend. De motieven om af te wijken van deze PPC-uitkomst liepen uiteen en varieerden per project. Op ambtelijk niveau ontstond een waar 'motievenvocabulaire'. Zo lagen er soms bestuurlijke afspraken tussen de minister en regionale overheden over de openingsdatum van de weg, waardoor het project onder tijdsdruk kwam en PPS, met zijn lange(re) transactietijd, onwenselijk werd gevonden. Voorbeelden van andere contra-motieven, waarbij men niet koos voor PPS ondanks een verwachte financiële meerwaarde, waren: er kunnen geen private optimalisaties worden behaald, er blijkt nauwelijks tijdwinst te behalen met PPS en de kennis van PPS ontbreekt (meer in Eversdijk, 2013).

In andere cases beïnvloedde de politiek-bestuurlijke factor het keuzeproces, en ging de politieke ratio boven de uitkomst van de PPC. Kortom, er lag soms wel een politieke wil om vóór PPS te kiezen, maar tegelijkertijd was er ook een bestuurlijke werkelijkheid waardoor de keuze vóór PPS niet doorging. Blijkbaar gaat het bij het overwegen van de keuze voor of tegen PPS bij rijksinfrastructuur dus niet enkel om financiële meerwaarde. Echter, dat was ooit wel een belangrijk motief van opeenvolgende kabinetten en Tweede Kamers om voor PPS te pleiten. We wijzen ook op het advies van de commissie-Ruding. Meerwaarde, ook wel aangeduid als value-for-money, betekent namelijk 'meer kwaliteit voor hetzelfde geld of dezelfde kwaliteit voor minder geld'.

Tijdens het casestudie-onderzoek en de PPC-analyses werden tal van micro-motieven gesignaleerd die de ambtelijke keuze rondom PPS moesten rechtvaardigen. Tabel 3 toont een overzicht van deze motieven die in de besluitvormingspraktijk schuilgaan achter de publieke keuze om een infrastructureel wegenproject wel of toch niet uit te voeren in een PPS-verband.

Tabel 3 Motieven pro en contra de toepassing van PPS in concrete projecten 


\begin{tabular}{|l|l|}
\hline Pro PPS & Contra PPS \\
\hline - Financiële meerwaarde & $\bullet$ Geen financiële meerwaarde \\
\hline - Kortere bouwtijd & $\begin{array}{l}\text { • Onvoldoende tijdwinst in } \\
\text { realisatiefase }\end{array}$ \\
\hline $\begin{array}{l}\text { - Omvang } \\
\text { onderhoudsareaal } \\
\text { voldoende groot }\end{array}$ & $\begin{array}{l}\text { • Geringe onderhoudscomponent } \\
\text { leidt tot versnippering wegennet }\end{array}$ \\
\hline $\begin{array}{l}\text { - Voldoende tijdsduur } \\
\text { onderhoudsperiode }\end{array}$ & • Duur onderhoudsfase te gering \\
\hline $\begin{array}{l}\text { - Opbouwen ervaring en } \\
\text { kennis }\end{array}$ & $\bullet$ Onvoldoende PPS-kennis \\
\hline $\begin{array}{l}\text { - Budgettair knelpunt van } \\
\text { overheid oplossen }\end{array}$ & • Deadlines project in \\
\hline $\begin{array}{l}\text { overeenkomsten } \\
\text { tendensen }\end{array}$ & • Hoge transactiekosten \\
\hline $\begin{array}{l}\text { - Politiek-bestuurlijke } \\
\text { preferentie }\end{array}$ & • PPS-perceptie van PPC-team en \\
\hline $\begin{array}{l}\text { - Besparen op } \\
\text { organisatiekosten }\end{array}$ & $\begin{array}{l}\text { P PPS-perceptie van PPC- } \\
\text { team en PPC-methodiek }\end{array}$ \\
\hline
\end{tabular}

Bron: Eversdijk, 2013

Uit tabel 3 blijkt dat twee onderdelen in de overheidsbesluitvorming, te weten de 'PPC-methodiek' en de 'PPS-perceptie van het PPC-team', mede van invloed zijn op het wel of niet toepassen van PPS. Dit bleek na analyse van de PPC-en. Zo zijn de verwachte meerwaarden (als PPCuitkomst) gebaseerd op aannames en omgeven met onzekerheidsmarges. Een andere aanname kan soms een behoorlijk verschil teweegbrengen in de hoogte van de verwachte financiële meerwaarde en zomaar leiden tot een andere keuze rondom PPS. Verder ontstond het beeld dat de perceptie die leden van het PPC-team hebben van PPS medebepalend is voor de PPC-uitkomst. Een perceptie die gebaseerd is op persoonlijke kennis van en ervaringen met PPS.

We concluderen: hoe rationeel de PPC ook wordt beargumenteerd, de keuze pro of contra PPS blijft afhankelijk van de voorkeuren en belangenafweging van de publieke besluitvormer die op een bepaald moment in de tijd de keuze maakt en zich daarover verantwoordt. De PPC biedt houvast in het keuzeproces, maar kiezen voor PPS op basis van het financiële 'meerwaardeprincipe' wordt in de praktijk overschat. 
Hoe de PPC uiteindelijk te waarderen? De uitkomst van een PPC-rapport (over wel of geen meerwaarde voor een PPS) geldt als fundament voor de publieke keuze voor wel of geen PPS. Over de werking en het gebruik van de PPC is tot op heden echter weinig bekend in de (inter)nationale PPSliteratuur. Door dit inzichtelijk te maken wordt de transparantie in de besluitvorming over wel of geen PPS verder vergroot. Dit inzicht is maatschappelijk relevant, omdat omvangrijke investeringsbeslissingen in infrastructuur voor een belangrijk deel op de PPC-uitkomst zijn gebaseerd. 29 PPC-rapporten maakten onderdeel uit van onze PPCanalyse. Op basis van deze omvangrijke onderzoekspopulatie kunnen robuuste uitspraken worden gedaan.

Respondenten die in de dagelijkse praktijk betrokken zijn bij het PPCproces, geven aan dat zij de PPC hetzij beschouwen als een knoppenpaneel hetzij als een blackbox. Bij sommigen leefde het beeld 'wat je uit de PPC wil laten komen, komt er ook uit'. Deze kwalificaties roepen de suggestie op dat de PPC-uitkomst beïnvloedbaar is. Waar komt dit beeld vandaan en wat betekent dit voor de kwaliteit van de PPC?

Uit de analyse blijkt dat de PPC een handig hulpmiddel is en een toegevoegde waarde heeft om de keuze van een overheidsbestuur te rationaliseren. De PPC-uitkomst moet in de besluitvorming over wel of geen PPS evenwel niet worden overschat. De PPC heeft namelijk ook zijn beperkingen. Ter illustratie noemen we er enkele.

Zo blijkt de uitkomst van een PPC gevoelig voor (inter)subjectiviteit. Het resultaat is afhankelijk van de perceptie, kennis en expertise van leden van het PPC-team (de opstellers) over PPS, waardoor ruimte voor interpretatieverschillen bestaat. Het (inter)subjectieve sluipt dus in het PPC-proces, terwijl het PPC-instrument toch bedoeld is om overwegingen in het PPS-keuzeproces te rationaliseren, zo hard mogelijk te maken. Ambtelijke invloed is dus niet alleen mogelijk ná een PPCuitkomst; ook tijdens de totstandkoming van de analyse van de financiële meerwaarde bestaat er ruimte voor ambtelijke afwegingen.

Ten tweede blijkt uit de PPC-analyse dat de verwachte meerwaardepercentages omgeven zijn met een bepaalde onzekerheid. De berekening van de meerwaarde is namelijk gebaseerd op uitgangspunten, aannames en parameters. Op basis van deze bevindingen kon dus worden geconcludeerd dat de PPC-uitkomst stuurbaar is naar een uitkomst die past bij de wens (wel of geen PPS) van de publieke besluitvormer(s). Of in de praktijk sprake is van bewuste manipulatie, is niet onderzocht; hier zijn ook geen aanwijzingen voor en dit kan dus ook niet worden gesteld. De ruimte daartoe bestaat in theorie echter wel; invloed op de PPC-uitkomst is wel mogelijk.

De PPC blijkt ook een begrensd instrument omdat de alliantievorm van PPS, de vorm die in de literatuur wordt bejubeld, feitelijk niet kan worden gekozen. 


\section{Vorm? Een keuze voor zekerheid}

Binnen het PPS-keuzeproces zijn twee cruciale keuzemomenten te onderscheiden voor een publieke besluitvormer. Ten eerste het moment om wel of niet te kiezen voor PPS. Wanneer de keuze pro PPS is, ontstaat vervolgens een tweede keuzemoment. Dit is het moment om voor een bepaalde PPS-vorm te kiezen. Dit brengt ons bij de vraag over de twee PPS-hoofdvormen. Wat levert deze discussie aan bevindingen op? Omdat politieke besluitvormers en hun adviseurs primair kiezen voor het beperken van politiek-bestuurlijke risico's is de keuze van de PPSvorm een secundair vraagstuk. Voor politieke bestuurders blijkt de PPSvorm vaak vooral een 'uitvoeringsissue'; iets van en voor ambtenaren. Hoe de samenwerking tussen publieke en private partijen ook geregeld wordt, welke vorm ook wordt gekozen, het draait voor een bestuurder (in elk publiek domein) hoofdzakelijk om doelen (zoals een aantal nieuwe wegen of wegverbreding), beleidsaanvaarding en het vermijden van politieke risico's.

Uit het PPS-onderzoek blijkt verder dat ongeacht de keuzeopties aan PPS-vormen publieke besluitvormers bij de realisatie van hun beleidsdoelen kiezen voor de drie Z's: zekerheden, zeggenschap en zelfbeschikking. Hoewel volgens de huidige stand in de normatieve PPSliteratuur bewuste risicoaanvaarding bij PPS wenselijk is om de meerwaarde van PPS te vergroten (Esselbrugge \& Teisman, 1998; Van Ham \& Koppenjan, 2002), streven overheidsbestuurders in de praktijk juist aanzienlijke risicobeperking na. Populair gesteld: ministers en topambtenaren willen zelf aan de knoppen kunnen zitten. Ter illustratie het volgende.

Een onderdeel van het ministerie van Financiën wil de risico's rondom PPS beperken en dus is men daar wat afkerig van een alliantievorm van PPS. Deze vorm wordt namelijk toegepast wanneer bij de opdrachtgever veel onduidelijkheden bestaan over de oplossing van een bepaald infrastructureel probleem en een alliantie zou moeten leiden tot verbinding tussen doelen van diverse partners en mogelijk zelfs doelverrijking. Vooraf is dan niet exact helderheid over de meest geschikte aanpak en het beste resultaat. In die situatie bestaan dus open einden (en risico's) en dat geeft een kans op 'discussie' in de verantwoording richting Tweede Kamer.

Indien voor PPS wordt gekozen, heeft DBFM op rijksniveau dus de voorkeur, omdat al veel vooraf contractueel kan worden geregeld. Risico's kunnen vooraf goed worden 'afgehecht', zoals dat heet, en verdeeld tussen partijen. Dit geeft overzicht en zekerheid. Daarmee is de vorm van PPS een minder relevant vraagstuk geworden voor publieke bestuurders, maar niet voor ambtenaren. 
De gedachte dat vanwege het politiek primaat ook vanzelfsprekend PPS volgt als PPS omarmd wordt in een regeerakkoord, blijkt op basis van onze analyse een naïeve gedachte. Het politiek primaat en de diffuse parlementaire meerderheidsvoorkeur zoals die rond nota's over PPS naar voren komt, blijken niet voldoende om PPS vlot en soepel van de grond te krijgen op rijksniveau, terwijl dit wel de verwachting is. Zonder druk vanuit het parlement was PPS er weliswaar nooit gekomen, maar die druk is in concrete gevallen bij de keuze pro of contra PPS niet altijd genoeg.

Verkeersministers waren op zich ook niet tegen PPS, maar hier lag zelden hun politieke prioriteit. De aanleg van wegen was wel van belang, maar PPS was voor meerdere ministers - zoals bij Camiel Eurlings vooral een uitvoeringskwestie; zij lieten de keuzen van wel of geen PPS bij infrastructurele projecten over aan Rijkswaterstaat. Anders gesteld, ministers hebben in de gaten dat je niet scoort met veel of weinig PPS, maar wel met wegenaanleg. Recent heeft verkeersminister Melanie Schultz van Haegen overigens wel ingezet op PPS, wat een breuk is met de praktijk uit het verleden.

Zijn politiek-bestuurlijke preferenties pro of contra PPS dan in de periode 1986-2011 altijd gebaseerd op projectinhoudelijke motieven in PPC-en, zoals verwoord door ambtenaren? Lang niet altijd. De inhoudelijke rationaliteit werd bij sommige projecten zelfs 'overruled' om tegemoet te komen aan de PPS-ambities vanuit de Tweede Kamer. Oftewel, bestuurlijke overwegingen om invulling te geven aan het kabinetsbeleid krijgen dan ineens de voorkeur boven de projectinhoudelijke adviezen vanuit de ambtelijke organisatie, zoals in de case Tweede Coentunnel, waar ambtenaren in eerste aanleg een PPSconstructie afraadden. Voldoen aan de parlementaire verwachtingen over PPS bevorderde dus weliswaar de keuze pro PPS, maar dit legitimeert de keuze pro PPS daarmee nog niet altijd voldoende. Er is doorgaans méér nodig. Soms is ook interbestuurlijke steun uit de regio van groot belang, moet de economische conjunctuur meezitten en moeten banken bereid zijn om in een PPS te stappen.

\section{Kritiek}

Is op de keuze pro PPS ook kritiek mogelijk? 'Samenwerking' heeft in ons dagelijkse leven een positieve connotatie en dit denkbeeld overheerst ook in de literatuur over publiek-private samenwerking. De verwachtingen over PPS zijn daardoor vaak hooggespannen, maar deze blijken niet altijd te sporen met de PPS-praktijk van weginfrastructurele projecten. Overigens is recent in de wetenschap een voorzichtige heroverweging waarneembaar van het geclaimde succes met PPS (Greve \& Hodge, 2013: 1, 211). Dit mede naar aanleiding van de bankencrisis.

Begrotingsinflexibiliteit. Naast de overwegend positieve retoriek die de PPS-literatuur vooralsnog domineert, stuitten we ook op nadelige effecten van PPS. Zo neemt zowel de zeggenschap van de 
volksvertegenwoordigers als de transparantie van de publieke besluitvorming af. En een rijkdom aan PPS-projecten leidt tot een afname van de begrotingsflexibiliteit en een toename van inflexibiliteit voor toekomstige ministers (ook Eversdijk, 2013).

Bureaucratie. De waargenomen toename van bureaucratie is opvallend te noemen, want die past niet in het gedachtegoed van PPS als element van de New Public Management-filosofie. Private inzet moest immers de efficiëntie en effectiviteit van het overheidsoptreden juist bevorderen en de ont-bureaucratisering stimuleren.

Gevolgen. Opvallend is verder dat publieke besluitvormers zowel gericht zijn op de verwachte financiële meerwaarde (denk aan de verplichte toepassing van de PPC) als op andere bestuurlijke aspecten, maar te weinig weten van de lange-termijn-gevolgen van PPS voor de maatschappij. In de projectpraktijk kennen PPS-overeenkomsten looptijden van twee tot soms drie decennia.

PPS biedt zeker voordelen, zoals een integrale aanpak van ontwerpen, bouwen, financieren en onderhouden van een weg, maar bestuurders en parlementen moeten zich niet te gemakkelijk rijk rekenen. De verwachte financiële meerwaarde, berekend met de PPC, is namelijk omgeven met onzekerheden, die tijdens de looptijd van de overeenkomst ook nog kan verdampen. De PPC-uitkomst biedt geen garantie, maar is een best possible guess.

\section{De toekomst van PPS in perspectief}

Wat betekenen dergelijke kritische onderzoeksbevindingen nu voor de toekomst van PPS bij de realisatie van weginfrastructuur in Nederland? Ook het kabinet-Rutte II heeft hoge verwachtingen van en ambities met PPS. Zo wijst minister Schultz van Haegen van Infrastructuur en Milieu medio 2011 dertig infrastructurele projecten aan die de potentie hebben om de komende vier à vijf jaar in PPS-vorm te worden gerealiseerd (Kamerstukken II 2011/12, 28 753, nr. 25, p. 2). Voor Rijkswaterstaat betekent dit een behoorlijke opgave, want van gemiddeld één DBFMproject per jaar tussen 2003 en 2011 (zie tabel 1) moet de organisatie nu bewegen naar gemiddeld zes PPS-projecten per jaar. Verder hoopt minister Schultz dat PPS in 2020 een vanzelfsprekendheid is, waarmee zij verder uitdrukking geeft aan de PPS-ambities bij infrastructuur.

We signaleren dat de rijksoverheid de laatste twee jaar in toenemende mate ingesteld raakt op DBFM, de concessievorm van PPS. Steeds meer ambtenaren hebben inmiddels kennis en ervaring opgedaan met de aanbesteding en uitvoering van deze contractvorm. Dat geldt ook voor marktpartijen; bouwondernemingen hebben hun organisaties steeds meer ingericht op PPS-projecten. Sommige creëren aparte PPSafdelingen. Nu stoppen met PPS zou niet wenselijk zijn gelet op de investeringen in de afgelopen jaren. 
Momenteel werkt Rijkswaterstaat aan een verdere modernisering van DBFM, waarbij leerervaringen moeten leiden tot verbeteringen in de DBFM-overeenkomst, zoals meer flexibiliteit tijdens de looptijd en een vereenvoudigd betalingsmechanisme.

Ondanks deze ontwikkelingen pleiten we voor meer bestuurlijke bewustwording en voor een minder dogmatisch streven naar PPS door publieke besluitvormers, volksvertegenwoordigers en andere beleidsmakers. Parlementsleden en bewindslieden zouden meer op de hoogte moeten zijn van de risico's en bedenkingen met betrekking tot PPS voordat zij PPS zo vurig najagen. Publieke keuzen voor wel of geen PPS zouden vaker gebaseerd moeten zijn op projectinhoudelijke overwegingen, meer evidence-based kunnen zijn, en minder op basis van 'non-proven' ideologische motieven. Maar of dit ooit werkelijkheid zal worden?

Deze constateringen worden nog eens versterkt door recent gepubliceerde resultaten van en ervaringen met PPS in het Verenigd Koninkrijk, het PPS-voorbeeldland bij uitstek. Zoals eerder vermeld moest het toepassen van PPS de efficiëntie in de bouw- en infraketen bevorderen en leiden tot reductie van overheidsuitgaven. Immers, door het integraal uitbesteden van diverse werkzaamheden (D, B en M) waren efficiëntiewinsten te behalen met PPS. De publieke uitgaven voor infrastructurele bouwprojecten zouden dalen door het toepassen van PPS. Deze verwachtingen blijken in het Verenigd Koninkrijk echter niet helemaal bewaarheid te gaan worden. HM Treasury, het ministerie van Financiën van het Verenigd Koninkrijk, dat tot op heden over het algemeen het meest positief communiceerde over PPS, maakt zich namelijk zorgen over het behalen van de beoogde value-for-money; de hoeksteen van PPS (HM, 2011: 7). PPS blijkt volgens de Britse auteurs een aantal zwakheden te bevatten waardoor ' (...), too often, PFI (...), failed to deliver value for money' (HM Treasury, 2012: 6). Zo bleek uit hun evaluatie dat tijdens de looptijd van een PPS-overeenkomst sprake is van

a. onvoldoende flexibiliteit,

b. onvoldoende transparantie over de financiële voortgang van het PPSproject, en dat soms sprake was geweest van

c. onverantwoorde overdracht van projectrisico's naar private partijen (HM Treasury, 2012: 5, 13).

Inmiddels zijn tal van maatregelen bedacht die de genoemde zwakheden moeten reduceren. Hiermee introduceert de Britse regering een nieuwe benadering van private financiering van publieke infrastructuur; een beleidswijziging in de oorspronkelijke 'PFI-policy' naar 'Private Finance 2' (ook wel PF2 genoemd).

Ondanks de cruciale maatregelen lijkt dit proces voor de Britse regering niet voldoende zekerheid te bieden. Aanvullend op de aangekondigde aanpassingen in de aanbestedingsdocumentatie deden de Britten namelijk een beroep op de relationele, zachte kant van de PPS-partners. 
Zo besloten zij in de loop van 2012 om met alle betrokkenen bij PPSprojecten, zoals aannemers, overheden en financiële instellingen, een gedragscode te ondertekenen, de zogenoemde code of conduct (HM Treasury, 2013). Met deze code doet de Britse overheid een moreel appèl op partijen uit de private sector om zich gezamenlijk in te spannen voor het bereiken van value-for-money. Hiermee probeert zij te voorkomen dat de honderden PPS-projecten de komende tientallen jaren gaan eindigen in een financieel drama. Kortom, zonder de PF2-maatregelen en de gedragscode is het bereiken van value-for-money met PPS in gevaar in het Verenigd Koninkrijk.

We concluderen dat het (in verregaande mate) betrekken van private partijen bij de realisatie van publieke voorzieningen niet automatisch leidt tot de gewenste financiële meerwaarde. Publieke besluitvormers en volksvertegenwoordigers moeten zich in Nederland ook niet rijk rekenen met PPS, zoals een blik op de situatie in Groot-Brittannië laat zien. Immers, de verwachte financiële meerwaarden, die in Nederland het fundament vormen van de besluitvorming over wel of geen PPS, zijn omgeven met onzekerheden en deze kunnen zelfs verdampen tijdens de projectuitvoering. Garanties worden vooraf niet gegeven.

\section{Afsluiting}

We sluiten af met enkele bevindingen. Achterliggende motieven en overwegingen van Nederlandse overheidsbesturen om dan wel en dan weer niet te kiezen voor publiek-private samenwerking (PPS) bleven tot voor kort onduidelijk. Diverse kabinetten predikten sinds het midden van de jaren tachtig uit de vorige eeuw weliswaar publiek-private samenwerking, maar daarmee was PPS nog geen feit. Wisselende motieven werden in nota's opgevoerd om PPS onvermijdelijk te maken, waarbij financiële meerwaarde een constante was, maar dat bleek niet genoeg. Om tot een concrete afweging te komen bij een bepaald project en PPS te bevorderen, werd een instrument ontwikkeld, de Public Private Comparator (PPC). Was dat een grote vondst: diffuse steun voor PPS plus de komst van een afwegingsinstrument? Dit instrument is in elk geval jarenlang ingezet. Door ons zijn mede daarom alle PPC-en uit de periode 1986-2011 die betrekking hebben op weginfrastructurele rijksprojecten aan analyse onderworpen. Tot welke bevindingen leiden de keuzeprocessen rond PPS?

De politieke wil noch financiële meerwaarde blijkt niet voldoende om op rijksniveau moeiteloos voor PPS te kiezen. Er hoort altijd een 'verhaal' bij het wel of niet kiezen van een concrete PPS, ook als er diffuse steun pro PPS bestaat. Diverse pushbewegingen vanuit de Tweede Kamer en diverse beleidsimpulsen waren nodig om omvangrijke infraprojecten in PPS-verband te realiseren; het beleid verkocht zichzelf niet.

Analyse van de toepassing van de PPC in de periode 1986-2011 toont aan dat per project wisselende motieven het gewenste PPS-beleid moesten rechtvaardigen, waaronder ook niet-politieke motieven. Het financiële 
afweginginstrument PPC objectiveert het PPS-keuzeproces weliswaar, maar van PPC-uitkomsten wordt ook wel afgeweken. De PPC-uitkomst determineert niet alles. Het bereiken van financiële meerwaarde bleek dus wel een officieel doel of motief, maar was in de praktische besluitvorming lang niet altijd de enige relevante factor. Dit betekent dat denkbeelden en hoge verwachtingen die in de PPS-literatuur overheersen, zoals dat financiële meerwaarde juist bepalend is, niet volledig blijken te sporen met de PPS-praktijk. Sterker gesteld, bestuurlijke afwegingen in plaats van financiële meerwaarde blijken vaak bepalender voor keuzen pro of contra PPS bij rijksinfrastructurele projecten, of ook van grote invloed.

Een te kritiseren praktijk? Niet voor personen die de technocratische determinatie door het financiële primaat een halt willen toeroepen, maar wel voor degenen die de bestuurlijke afwegingen soms grillig vinden. Want als de financiële meerwaarde niet of beperkt telt, wat is dan van hogere orde? Dat blijkt per project te verschillen. Naast projectinhoudelijke motieven blijken ook determinanten als de politiekbestuurlijke tijdgeest, de rol van ambtenaren en de aanvaarding van een keuze van PPS in de interbestuurlijke context medebepalend te zijn voor een soepele in- en uitvoering van PPS-beleid.

\section{Literatuur}

Barzelay, M. (2001). The New Public Management. Berkeley: University of California Press.

Bekker, R. (2012). Marathonlopers rond het BinnenhofTopambtenaren bij het rijk 1970-2010. Den Haag: Boom Lemma uitgevers.

Bovens, M.A.P., Hart, P. 't, Twist, M.J.W. van, \& Rosenthal, U. (2001). Openbaar bestuur. Deventer: Kluwer.

Esselbrugge, M., \& Teisman, G.R. (1998). Publiek-privaat management bij kluwens van reeksen infrastructuurprojecten. In Management in overheidsorganisaties. Alphen aan den Rijn: Samsom, december, pp. 53-70.

Eversdijk, A.W.W. (2013). Kiezen voor publiek-private samenwerking (dissertatie). Den Haag: Boom Lemma uitgevers.

Eversdijk, A.W.W., \& Korsten, A.F.A. (2008). De bestuurskundige mythe van verbindend PPS-management - de Tweede Coentunnel als illustratie. Bestuurswetenschappen, 62 (3), 29-56.

Greve, C., \& Hodge, G. (2013). Rethinking Public-Private Partnerships Strategies for turbulent times. New York: Routledge.

Greve, C. (2008). Contracting for Public Services. New York: Routledge. 
Ham, H. van, \& Koppenjan, J. (red.). (2002). Publiek-private samenwerking bij transportinfrastructuur; wenkend of wijkend perspectief. Utrecht: Lemma.

HM Treasury. (2011). Making savings in operational PFI contracts. London, juli.

HM Treasury. (2012). A new approach to public private partnerships. London, december.

HM Treasury. (2013). Code of Conduct for Operational PFI and PPP contracts. London, juni.

Hodge, G.A., \& Greve, C. (2007). Public-Private Partnerships: An international performance review, Public Administration Review, 67 (3), 545-558.

Hodge, G.A., Greve, C., \& Boardman, A.E. (Eds.). (2010). International Handbook on Public-private Partnerships. Cheltenham: Edward Elgar.

Klijn, E.H. (2008). It's the management, stupid! - Over het belang van management bij complexe beleidsvraagstukken. Den Haag: Boom Lemma uitgevers.

Klijn, E.H., \& Teisman, G.R. (2005). Public-private partnerships as the management of co-production: strategic and institutional obstacles in a difficult marriage. In G.A. Hodge \& C. Greve (Eds.), The challenge of public-private partnerships: Learning from international experience (pp. 95-116). Cheltenham: Edward Elgar.

Klijn, E.H., \& Twist, M.J.W. van. (2007). Publiek-private samenwerking in Nederland - Overzicht van theorie en praktijk. $M \& O, 3 / 4,156-170$.

McLaughlin, K., Osborne, S.P., \& Ferlie, E. (Eds.). (2002). New Public Management - Current trends and future prospects. London:

Routledge.

Minister van Infrastructuur en Milieu. (2012). Speech op het congres PPS Werkt! Den Haag, 30 mei.

Ministerie van Verkeer en Waterstaat \& het ministerie van Financiën. (2008). Publiek-private samenwerking. Kamerstukken II 2008/o9, 28 753, nr. 15 .

Osborne, D., \& Gaebler, T. (1992). Reinventing government-How the entrepreneurial spirit is transforming the public sector. Reading: Addison-Wesley. 
PPC A12 Gouda-Woerden-Oudenrijn (Utrecht West), 12 juni 2007.

PPC A12 Utrecht-Maarsbergen-Veenendaal, 10 november 2006.

PPC A15 Maasvlakte-Vaanplein, 12 januari 2006.

PPC A1-A6, 26 januari 2007.

PPC A2 Passage Maastricht, 11 augustus 2006.

PPC A2-A76 Maatregelen Limburg, 6 juli 2006.

PPC A4 Steenbergen, 27 maart 2007.

PPC A50 Ewijk-Valburg-Grijsoord, 7 juli 2007.

PPC A9 Omlegging Badhoevedorp, 5 juni 2008.

PPC Delft-Schiedam, 2004 en oktober 2008.

PPC Extra spuicapaciteit Afsluitdijk, 25 augustus 2006.

PPC Maasroute-Verbreding Julianakanaal-Sluis Limmel, 22 december 2009.

PPC N18 Varsseveld-Enschede, 1 december 2007 en 19 november 2010.

PPC N31 Haak om Leeuwarden, Deloitte, september 2007.

PPC N31 Haak om Leeuwarden - Actualisatie, Den Haag, 25 november 2009.

PPC N31 Haak om Leeuwarden - Update 2008-2009, Leeuwarden, 6 februari 2009.

PPC N31 Hemriksein-Nijega, 19 mei 2000.

PPC Omlegging Zuid-Willemsvaart, 17 december 2007.

PPC Schiphol-Amsterdam-Almere, 18 juli 2008.

PPC Tweede Coentunnel, 25 juni 2004.

PPC Verdubbeling RW33 Assen-Zuidbroek, november 2007.

PPC ViA15 (A12/A15 bereikbaarheid Arnhem-Nijmegen), 15 juli 2010.

PPC Wilhelminakanaal Tilburg, december 2009. 
PPC Zeetoegang IJmond, 22 juli 2009.

Ruding, H.C.O.R. et al. (2008). Op de goede weg en het juiste spoor. Den Haag, mei.

Skelcher, C. (2005). Public-private partnerships and hybridity, In E. Ferlie, L.E. Lynn \& C. Pollitt (Eds.), The Oxford Handbook of Public Management (pp. 347-371). Oxford: Oxford University Press.

(C) Boom bestuurskunde 